\title{
Anterior Chamber Depth After Phacovitrectomy [Letter]
}

\author{
Maddalena De Bernardo (iD \\ Ilenia Di Paola \\ Nicola Rosa (iD \\ Department of Medicine, Surgery and \\ Dentistry, "Scuola Medica Salernitana", \\ University of Salerno, Baronissi, Salerno, \\ Italy
}

\section{Dear editor}

We were very interested in the paper by Katz et $\mathrm{al}^{1}$ concerning the role of anterior chamber depth (ACD) on post-operative refractive error after phacovitrectomy, published in your journal, because in the past we published some studies concerning the ACD changes after surgery, mostly after refractive surgery. ${ }^{2}$

For this reason, we would like to make some comments on two findings of this paper, namely the significant ACD increase after phacovitrectomy and the nonsignificant axial length (AL) increase.

Regarding the ACD increase, it could be speculated that, as the IOLMaster measures from the corneal epithelium to the retinal pigmented epithelium, the increase could be related to a corneal thickness increase due to a subclinical edema. $^{3-5}$

We do not think this could be the case, as it is well known that in all patients after cataract surgery an increase in ACD occurs, due to the difference in thickness between the natural lens and the intraocular lens, and the phacoemulsification is also suggested to improve the aqueous drainage in patients with narrow angle glaucoma, so it is not the vitrectomy which gives the ACD increase, but the change in lens thickness. ${ }^{6}$ To prove that the increase is vitrectomy-related, a comparison with non vitrectomized eyes should have been performed, but unfortunately this comparison was not done.

However, the ACD measurements should have been performed with other instruments too, because in clinical practice such measurements in pseudophakic eyes can be challenging.

Concerning the $\mathrm{AL}$ changes, it has been widely shown that after cataract surgery, both in patients measured with ultrasound and IOLMaster, a significant AL decrease has been detected. ${ }^{7}$ Four hypotheses could explain these differences in AL: the reduction in $\mathrm{Km}$ after the surgery could flatten the anterior chamber and consequently reduce the AL; the lens extraction causes a decrease in the volume of the eye, with a subsequent decrease in the AL; incorrect estimation in pseudophakic eyes, despite the change in AL measurement modality from phakic to pseudophakic; and the last hypothesis could be that the incorrect measurement is the preoperative one because the real refractive index of the implanted lens is known, whereas the refractive index of the human lens is not. ${ }^{7}$

In our opinion the non-significant decrease found in the study by Katz et al could be explained by the limited number of examined patients. 
In conclusion, further studies with larger numbers of patients, comparing phaco-technique versus phacovitrectomy, are needed before concluding that the increase in refractive error in these patients in the combined surgery is related to the ACD changes.

\section{Disclosure}

The authors report no conflicts of interest in this communication.

\section{References}

1. Katz G, El Zhalka F, Veksler R, Ayalon A, Moisseiev E. The role of anterior chamber depth on post-operative refractive error after phacovitrectomy. Clin Ophthalmol. 2021;15:2111-2115. doi:10.2147/ OPTH.S309302

2. De Bernardo M, Borrelli M, Imparato R, Cione F, Rosa N. Anterior chamber depth measurement before and after photorefractive keratectomy. Comparison between IOLMaster and pentacam. Photodiagnosis Photodyn Ther. 2020;32:101976. doi:10.1016/j.pdpdt.2020.101976
3. Rosa N, De Bernardo M. Central corneal thickness determination in corneal edema. Graefes Arch Clin Exp Ophthalmol. 2017;255 (6):1251-1252. doi:10.1007/s00417-017-3634-9

4. De Bernardo M, Rosa N. Comparison of specular microscopy and ultrasound pachymetry before and after cataract surgery. Graefes Arch Clin Exp Ophthalmol. 2017;255(4):837-838. doi:10.1007/ s00417-017-3604-2

5. De Bernardo M, Vitiello L, Abbinante G, et al. Comparison between two devices in the detection of corneal thickness changes after cataract surgery. Sci Rep. 2021;11(1):6709. doi:10.1038/s41598021-86158-6

6. Dooley I, Charalampidou S, Malik A, Loughman J, Molloy L, Beatty S. Changes in intraocular pressure and anterior segment morphometry after uneventful phacoemulsification cataract surgery. Eye. 2010;24(4):519-527. doi:10.1038/eye.2009.339

7. De Bernardo M, Salerno G, Cornetta P, Rosa N. Axial length shortening after cataract surgery: new approach to solve the question. Transl Vis Sci Technol. 2018;7(6):34. doi:10.1167/ tvst.7.6.34

Dove Medical Press encourages responsible, free and frank academic debate. The content of the Clinical Ophthalmology 'letters to the editor' section does not necessarily represent the views of Dove Medical Press, its officers, agents, employees, related entities or the Clinical Ophthalmology editors. While all reasonable steps have been taken to confirm the content of each letter, Dove Medical Press accepts no liability in respect of the content of any letter, nor is it responsible for the content and accuracy of any letter to the editor.

Clinical Ophthalmology

\section{Dovepress}

\section{Publish your work in this journal}

Clinical Ophthalmology is an international, peer-reviewed journal covering all subspecialties within ophthalmology. Key topics include: Optometry; Visual science; Pharmacology and drug therapy in eye diseases; Basic Sciences; Primary and Secondary eye care; Patient Safety and Quality of Care Improvements. This journal is indexed on PubMed
Central and CAS, and is the official journal of The Society of Clinical Ophthalmology (SCO). The manuscript management system is completely online and includes a very quick and fair peer-review system, which is all easy to use. Visit http://www.dovepress.com/ testimonials.php to read real quotes from published authors. 